\title{
Atmospheric dust concentration record from the Hercules Névé firn core, northern Victoria Land, Antarctica
}

\author{
V. Maggi, ${ }^{1}$ J. -R. Petit ${ }^{2}$ \\ ${ }^{1}$ Dipartimento di Scienze dell'Ambiente e del Terrotorio, Università di Milano, Via Emanueli 15, I-20126 Milan, Italy \\ ${ }^{2}$ Laboratoire de Glaciologie et Géophysique de l'Environnement du CNRS, 38402 Saint-Martin-d'Hères Cedex, France
}

\begin{abstract}
During the ninth Italian Antarctic Expedition, a $22 \mathrm{~m}$ deep firn core was drilled on the Hercules Névé (HN) in the Transantarctic Mountains, northern Victoria Land, Antarctica. The continuous dust record from HN, spanning 70 years from 1927 to 1994, displays sharp differences between the upper $15.5 \mathrm{~m}$ and the bottom part. The background of dust concentration in the upper part is quite homogeneous, with values around $6.5 \times 10^{3}$ particles $\mathrm{g}^{-1}$ of water, and some peaks reaching maximum values of 1.0 $1.5 \times 10^{4}$ particles $\mathrm{g}^{-9}$ of water. In this part the volume-size distribution of particles shows a relative maximum around $0.9 \mu \mathrm{m}$, while a second maximum occurs for particles larger than $12 \mu \mathrm{m}$. The larger particles are likely to have a local origin, while the small-size component may be representative of long-range transport dust. Below $15.5 \mathrm{~m}$ the record shows higher values in both background and peak concentration, with mean values of $1.6 \times 10^{4}$ particles $\mathrm{g}^{-1}$. The volume-size distribution changes from 0.9 to $1.5 \mu \mathrm{m}$ in parallel with the increase of dust concentration. The dust record suggests significant increases in concentration for the periods 1932-42 and 1951-64. It suggests some correlations with precipitation anomalies over South America and indirectly supports the hypothesis that small-sized dust at HN may originate from South America.
\end{abstract}

\section{INTRODUCTION}

Insoluble mineral dust is present in the normal troposphere, and in terms of mass has been estimated to be $15 \%$ of the total aerosol (Pye, 1987). This dust originates mainly from continental areas where wind erosion is dominant (Shaw, 1989). Minor quantities of dust may be related to forest fires that produce ash and other insoluble organic particles. The evaluation of this input is important because atmospheric dust has a substantial influence on the atmospheric optical depth and regional and/or global radiative budget (Tegen and others, 1996; Moulin and others, 1997).

In Antarctica, long records of atmospheric dust concentration, covering the last climatic cycle or a fraction of it, have been obtained from the Vostok station and Dome C ice cores (Royer and others, 1983; Mounier, 1988; Petit and others, 1990). Mosley-Thompson andThompson (1982) used the seasonal variation of atmospheric dust in the South Pole ice core, coupled with other records, to carry out a dating that covered the past 900 years. A goodcorrelation has been found between the atmospheric dust and the stable-isotope records in both Antarctica and Greenland, as well as during the main glacial-interglacial transitions and during their interstadial changes (i.e. fast variation in Greenland ice cores) (Royer and others, 1983; Hammer and others, 1985; Petit and others, 1990; Johnsen and others, 1992; Dansgaard and others, 1993).

During the ninth Italian Antarctic Expedition (Programma Nazionale Ricerche in Antartide; PNRA), a firn core was drilled to a depth of $22 \mathrm{~m}$ at the Hercules Névé (HN) site. The site is $100 \mathrm{~km}$ inland and $2960 \mathrm{~m}$ a.s.l., $150 \mathrm{~km}$ north of the Terra Nova Bay Italian station $\left(73^{\circ} 06^{\prime} 22^{\prime \prime} \mathrm{S}\right.$, $165^{\circ} 27^{\prime} 47^{\prime \prime} \mathrm{E}$ ) (Fig. 1), and is mainly characterised by the ab-

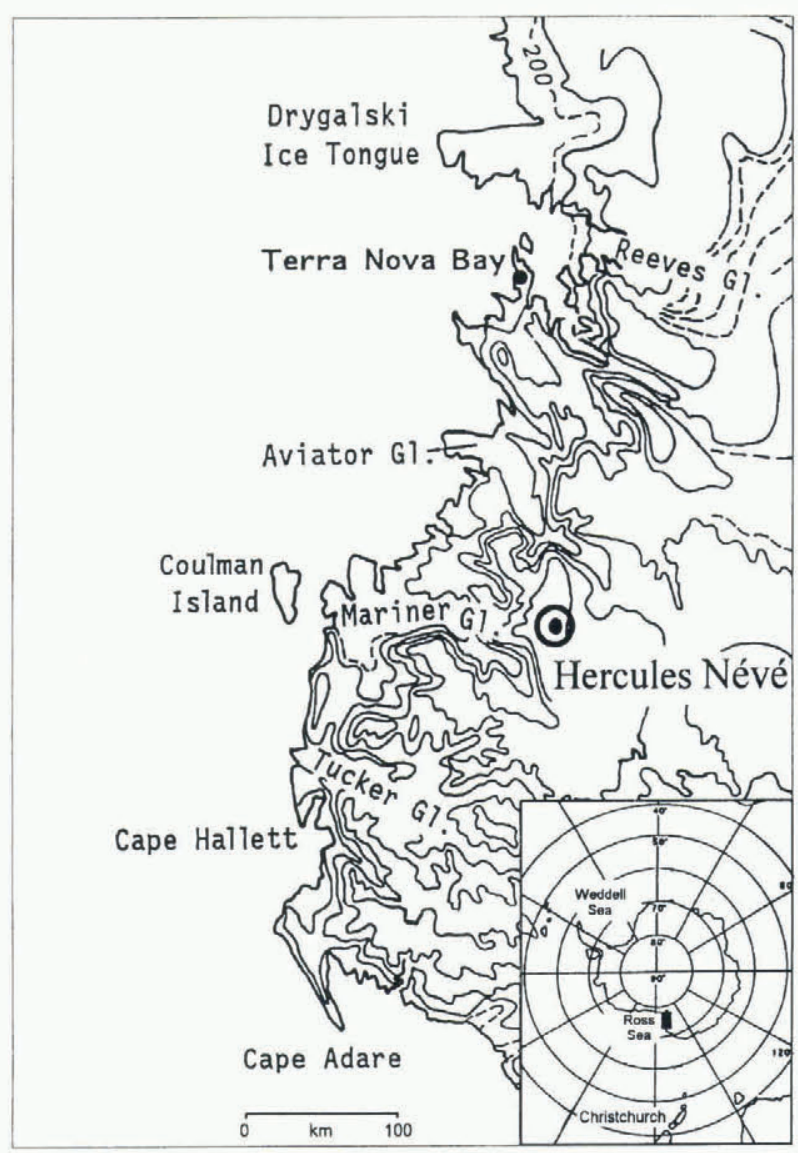

Fig. 1. Map of northern Victoria Land, showing the drillingsite location on the Hercules. Névé and the Terra Nova Bay Italian station. 

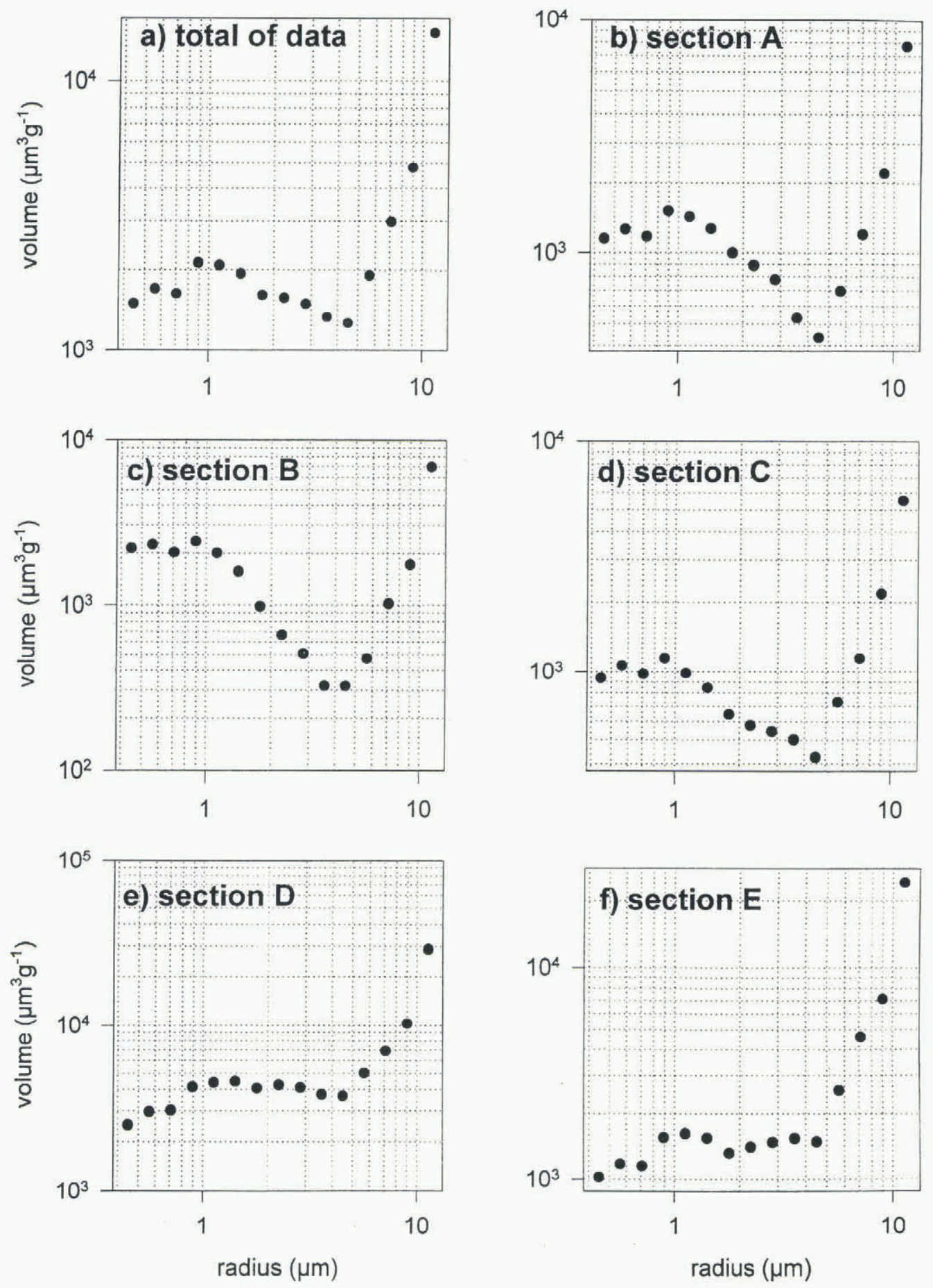

Fig. 2. Volume distribution vs radius of the dust particles for the total record and for each of the sections $A-E$.

sence of katabatic winds from the plateau (personal communication from B. Stenni and others, 1997). The site is on an ice divide between two major HN glacial fluxes, the first southward, in the direction of the Ross Sea (Meander Glacier), and the second northward, in the direction of the Pacific Ocean through the Evans Névé and Rennick Glacier.

The $22 \mathrm{~m}$ HN firn core spans about 70 years from the Antarctic summer 1993-94 to $1927( \pm 1)$. This dating was carried out by annual counting of all of the records obtained from the core (stable isotopes, ion chemistry, mineral dust, tritium analyses; Maggi and others, 1998). The annual accumulation rate has been calculated to be $16 \mathrm{~g} \mathrm{~cm}^{-2} \mathrm{a}^{-1}$, the same value as that obtained from another firn core drilled $3 \mathrm{~km}$ to the north (personal communication from B. Stenni and others, 1997).
The main objective of this work was to investigate the transport and deposition of atmospheric dust to northern Victoria Land.

\section{METHODS}

The drilling was done using a stainless steel SIPRE corer with fibreglass elongation. A mean annual temperature of $-33.0^{\circ} \mathrm{C}$ was measured at a depth of $10 \mathrm{~m}$, after a 24 hour stabilisation period, using a PT100 probe. The recovered cores $(10 \mathrm{~cm}$ in diameter and 50-90 cm long) were weighed for density. The maximum density at the bottom of the core was $0.63 \mathrm{~g} \mathrm{~cm}^{-3}$ (Maggi, 1996). For transportation to the 


\section{Hercules Névé}

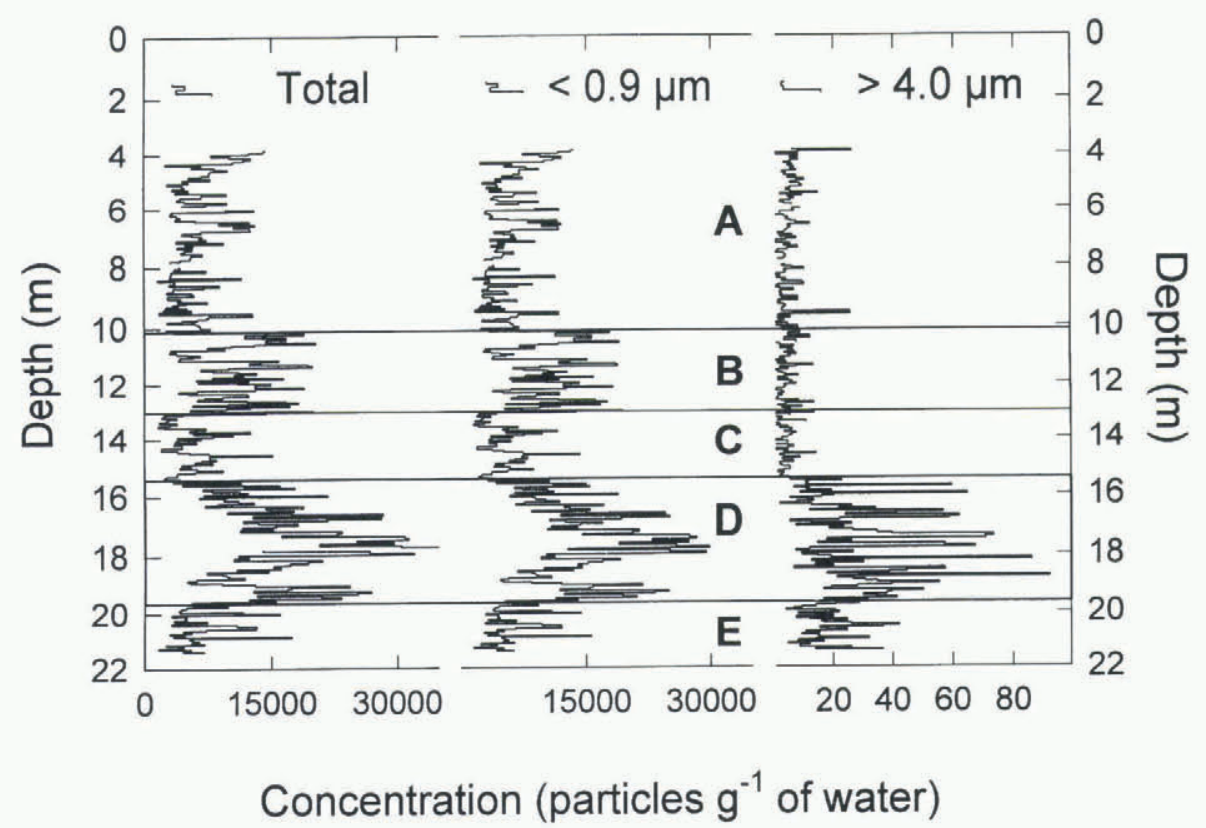

Fig. 3. H.N dust-concentration records of the total particles, particles smaller than $0.9 \mu \mathrm{m}$ and particles larger than $4.0 \mu \mathrm{m}$ in radius.

laboratory the core pieces were sealed in polyethylene plastic bags.

The samples were prepared at the Laboratoire de Glaciologie et Géophysique de l'Environnement (LGGE), Grenoble, France. The external $1-1.5 \mathrm{~cm}$ of the cores was removed using a mechanical lathe with stainless-steel tools, and the inner part $(7-8 \mathrm{~cm}$ diameter) was cut into $4-6 \mathrm{~cm}$ sections on a horizontal-flow bench (class 100). More than 500 samples were prepared for the analyses, with approximately $70 \mathrm{~cm}^{3}$ of water in the upper samples and $125 \mathrm{~cm}^{3}$ in the lower samples. These samples were divided into three parts: one for chemical analysis $\left(35-60 \mathrm{~cm}^{3}\right.$ of water), one for stable-isotope content $\left(15-35 \mathrm{~cm}^{3}\right)$ and one for dust studies $\left(15-35 \mathrm{~cm}^{3}\right)$. The dust samples were measured in a clean laboratory (class 10.000, with positive pressure).

Dust concentration and size classification were measured by liquid counting using a Coulter Counter TA2. The number of particles and volume were divided into 16 classes, ranging from 0.3 to $12 \mu \mathrm{m}( \pm 5 \%)$ in radius. In the laboratory procedure, the first channel was rejected because electrical noise could disturb the final counting (Mounier, 1988). After the counting analysis, the single samples were filtered using Nucleopore polycarbonate filters $(0.4 \mu \mathrm{m}$ hole diameter) for future microparticle analyses.

\section{RESULTS}

A plot of volume distribution as a function of particle radius for the entire record is shown in Figure 2a. The data for particles in the radius range $0.4-4.0 \mu \mathrm{m}$ could be fitted with a log-normal distribution, typical of atmospheric dust (Pye, 1987). The mode is close to $0.9 \mu \mathrm{m}$, compared to $1.0 \mu \mathrm{m}$ found for particles in the Vostok ice core drilled in central East Antarctica (Petit and others, 1990). This mode represents the mean value for the long-range transport particles, generally related to remote source areas. For particles greater than $4.0 \mu \mathrm{m}$, the volume distribution increases, reaching a maximum value for the largest measured particles
$(12.0 \mu \mathrm{m})$. These larger particles may be related to shortrange transport both from local dust sources, probably originating from the weathering of the rocks that outcrop in the HN area, and from the sedimentary deposits at the glacier margins and in deglaciated areas.

The record of total dust concentration against depth is shown in Figure 3, as well as the record of small-mode particles concentration (radius range $0.4-0.9 \mu \mathrm{m}$ ) and largemode particles concentration (radius $>4.0 \mu \mathrm{m}$ ).

The record is characterised by lower concentration levels down to $10 \mathrm{~m}$, at $13-15.5 \mathrm{~m}$ and below $19 \mathrm{~m}$. Increases of dust concentration are mainly located at $10-13 \mathrm{~m}$ and $15.5-19 \mathrm{~m}$. For this reason, the dust record has been subdivided into five sections $(\mathrm{A}-\mathrm{E})$, using the mean values of dust concentration (Fig. 3; Table 1). The upper section, A (from surface to $10 \mathrm{~m}$ ), has a mean concentration of $6.5 \times 10^{3}$ particles $\mathrm{g}^{-1}$, with maximum values of $1.0-1.5 \times 10^{4}$ particles $\mathrm{g}^{-1}$. Section $\mathrm{B}(10-13 \mathrm{~m})$ has twice the mean concentration levels of section $\mathrm{A}\left(1.1 \times 10^{4}\right.$ particles $\left.\mathrm{g}^{-1}\right)$, with peaks up to $2.0 \times 10^{4}$ particles $\mathrm{g}^{-1}$. In section $\mathrm{C}(13-15.5 \mathrm{~m})$, the concentrations are close to those of section $\mathrm{A}$, with a mean value of $5.0 \times 10^{3}$ particles $\mathrm{g}^{-1}$. The concentration record for particles with a radius less than $0.9 \mu \mathrm{m}$ is, for the first $15.5 \mathrm{~m}$, similar to the record for the total number of particles (Fig. 3). By contrast, the record for the larger particles is more

Table 1. Depth, mean and total dust concentration (number of particles $g^{-1}$ ) for sections $A-E$ of the $H \mathcal{N}$ record

\begin{tabular}{ccrrr}
\hline Section & Depth & $<0.9 \mu m$ & $>4.0 \mu m$ & Total \\
& $\mathrm{m}$ & & & \\
\hline A & $0-10$ & 6096.8 & 4.8 & 6520.1 \\
B & $10-13$ & 11086.9 & 3.8 & 11626.3 \\
C & $13-15.5$ & 4915.1 & 3.9 & 5194.8 \\
D & $15.5-19$ & 14427.2 & 28.6 & 15930.4 \\
E & $19-21$ & 5760.7 & 17.9 & 6282.0 \\
\end{tabular}




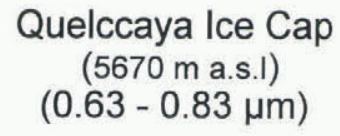

$(0.63-0.83 \mu \mathrm{m})$

\section{South America \\ precipitation \\ anomalies}

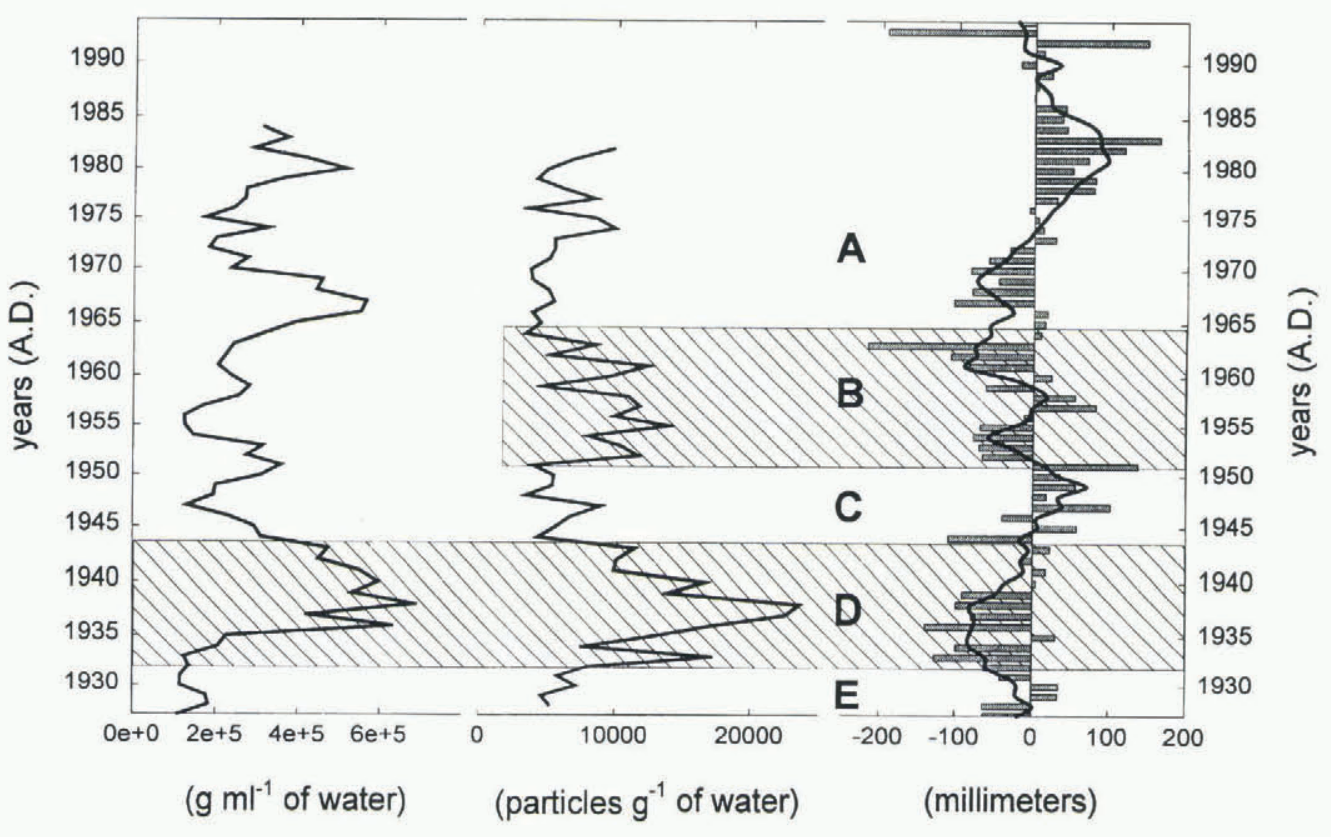

Fig. 4. Comparison between the $H \mathcal{N}$ dust-concentration record (mean annual value), the Quelccaya Ice Cap dust-concentration record (Thompson, 1992) and the South American (10-30 S) precipitation anomalies (Hulme, 1991).

uniform, without the variation found in the other particlesize ranges. The larger particles show a constant concentration from the top to $15.5 \mathrm{~m}$, with a mean value of 4-5 particles $\mathrm{g}^{-1}$. Therefore, the increase of dust concentration in section $\mathrm{B}$ of the record is due almost exclusively to the small particles. This feature may be related to an increase of dust input from remote sources, without the influence of local sources.

Section D (15.5-19 m) has the highest levels of dust concentration for the whole record, in terms of both the mean value $\left(1.6 \times 10^{4}\right.$ particles $\left.\mathrm{g}^{-1}\right)$ and the peak values (more than $3.0 \times 10^{4}$ particles $\left.\mathrm{g}^{-1}\right)$. In the lowest section, E (19$21 \mathrm{~m}$ ), dust concentrations decrease to values close to those in sections A and C (Table 1). The concentrations of the large particles (Fig. 3) are very similar to those of the small particles $(<0.9 \mu \mathrm{m})$. In sections $\mathrm{D}$ and $\mathrm{E}$ the mean concentrations of the large particles are respectively 7 and 4 times greater than in the upper sections, A-C.

The upper $15.5 \mathrm{~m}$, sections A-C, show similar volumesize distributions (Fig. 2b-d), with the mode of the volume distribution close to $0.9 \mu \mathrm{m}$, a minimum around $4.0 \mu \mathrm{m}$ and a maximum in the larger particle range. In section $\mathrm{D}$, the mode occurs for a radius of approximately $1.5 \mu \mathrm{m}$ (Fig. 2e), but without the well-marked minimum around $4.0 \mu \mathrm{m}$. In section $\mathrm{E}$, the size distribution of the particles shifts back to small values, with the mode close to $1.1 \mu \mathrm{m}$ (Fig. 2f) and still with the minimum around $4.0 \mu \mathrm{m}$ unpronounced.

The shift in the volume-distribution mode from $1.5 \mu \mathrm{m}$ for section D to $0.9 \mu \mathrm{m}$ (close to the East Antarctic value of $1.0 \mu \mathrm{m}$ from Vostok ice core) may be related to changes both in source areas and in atmospheric dynamics. To understand these shifts it is important to evaluate the availability of insoluble particles from source areas, normally related to drought periods and/or atmospheric circulation changes. Identification of dust sources is one of the main problems for understanding the atmospheric dust record from ice and firn cores. Using Nd and Sr isotopes, Grousset and others (1992) and Basile and others (1997) found that the source area of atmospheric dust for the central section of East Antarctica (Dome C and Vostok) is South America, mainly Patagonia in Argentina. From the size distribution of dust particles at $\mathrm{HN}$, we believe that the largest particles are most likely to be of local origin. For smaller-mode particles we have as yet no geochemical information to decipher the geographical origin of the dust.

The HN firn core, dated by direct comparison of seasonal stable-isotope signals, major ions and the dust record, and using the tritium concentration as a control, permits the analysis of the dust-loading in the period 1927-94 (Fig. 4). The two main events in terms of concentration observed in the record are well defined temporally. The first (section D) spans around 10 years between 1932 and 1942, and the second (section B) the period 1951-64. In Figure 4, the 1932-42 dusty period seems evidenced also by the Quelccaya Ice Cap record (Thompson, 1992), the unique record of atmospheric dust from South America, part of which covers the same time-span as the $\mathrm{HN}$ record. The correspondence of events in this period may be related to atmospheric circulation changes or to changes in the South American dust source, and especially to times of intense drought (e.g. the "Dust Bowl" which occurred in North America). In fact, the record of mean precipitation anomalies in South America (Hulme, 1991; Houghton and others, 1996) shows, for the same period, negative values both in the annual average and in the 5 year moving average (Fig. 4). These features in the precipitation anomaly record, related to the El NiñoSouthern Oscillation (Houghton and others, 1996), seem to occur 2-3 years in advance of the $\mathrm{HN}$ dust peak.

The 1951-64 dusty period in HN, like the previous one, seems to be represented in the record of South American precipitation anomalies. The mean annual values of the precipitation anomalies, and the 5 year moving average, are 
generally negative, indicating another drought period. On the other hand, there is no clear correlation with the Quelccaya record; this record seems to anticorrelate with HN for the 1945-75 period.

\section{CONCLUSIONS}

$\mathrm{HN}$ is a good site to investigate the evolution of atmospheric dust, in terms of concentration and size distribution, over northern Victoria Land. The high values of $\mathrm{HN}$ firn-core dust concentrations measured from 15.5 to $21 \mathrm{~m}$ (AD 192742) were observed in the records of both small $(<0.9 \mu \mathrm{m})$ and large particles $(>4.0 \mu \mathrm{m})$.

In the upper $15 \mathrm{~m}$ of the record, covering the last 50 years, the differences in terms of dust concentration between small and large particles (section B; Fig. 3) are likely related to long-range transport changes, but not in the local circulation. The lack of correspondence between the Quelccaya and HN dust records (sections A-C) can exclude the large-scale variations in terms of atmospheric influences on the dust sources, and we have no direct evidence that the dust originated in South America. However, there is a correlation between the increase in dust concentration from 1951 to 1964 in the HN core and precipitation anomalies for the same period in South America. This correlation would suggest a possible influence of drought events on these dust events. The increased concentration of biomassburning chemical species (Udisti and others, 1998) provides further evidence of these possible drought events.

Changes in size distribution, indicated primarily by shifts of mode in particles less than $4.0 \mu \mathrm{m}$, may be related to modifications in atmospheric transport or its turbulence. These shifts, from 1.1 to $1.5 \mu \mathrm{m}$ for the $1927-42$ period, and from 1.5 to $0.9 \mu \mathrm{m}$ for the period after 1942, underline that these changes are due to large-scale changes in atmospheric dynamics. The 1932-42 dusty period in HN may be linked partly to the drought and precipitation anomalies in South America, as well as to a period with a more turbulent atmosphere. On the other hand, the uniform size distribution of dust particles observed since 1942 suggests that the dust-concentration changes in the period 1951-64 may be related to an increase of dust flux in northern Victoria Land, and not to the general increase of continental deflation of the source areas.

Our results suggest that atmospheric dynamics, with more turbulence and more transport capability, have occurred in the past, but at this time it is not possible to evaluate the magnitude of these changes (or whether they are related to global changes or only to more meridional transport). Finally, the comparison between drought periods (precipitation anomalies) and atmospheric-dust load cannot exclude South America as a source area of the longrange dust that reaches northern Victoria Land and East Antarctica, as observed for the Last Glacial Maximum and other cold periods (Grousset, 1992; Basile, 1997).

\section{ACKNOWLEDGEMENTS}

The research reported here was carried out in the framework of a project on glaciology and palaeoclimatology of the Programma Nazionale di Ricerche in Antartide, and supported by ENEA. The authors thank the Italian Antarctic Project (PNRA) and the ninth Italian Antarctic Expedition's logistic personnel for help during the drilling operations. Special thanks to G. Orombelli for helpful discussions during the work. V. Maggi thanks the Italian National Research Council (CNR) for a grant to visit LGGE, Grenoble.

\section{REFERENCES}

Basile, I., F. E. Grousset, M. Revel, J. R. Petit, P. E. Biscaye and N. I Barkov: 1997. Patagonian origin of glacial dust deposited in East Antarctica (Vostok and Dome C) during glacial stages 2, 4 and 6. Earth Planet. Sci. Lett., 146 (3-4), 573-589.

Dansgaard, W. and 10 others. 1993. Evidence for general instability of past climate from a 250-kyr ice-core record. Nature, 364 (6434), 218-220.

Grousset, F. E. and 6 others. 1992. Antarctic (Dome C) ice-core dust at $18 \mathrm{ky}$ BP: isotopic constraints on origin. Earth Planet. Sci. Lett., 111 (1), 175-182.

Hammer, C. U., H. B. Clausen, W. Dansgaard, A. Neftel, P. Kristinsdottir and E. Johnson. 1985. Continuous impurity analysis along the Dye 3 deep core. In Langway, C. C., Jr, H. Oeschger and W. Dansgaard, eds. Greenland ice core: geophysics, geochemistry, and the environment. Washington, DC, American Geophysical Union, 90-94. (Geophysical Monograph 33.)

Houghton, J.T., L. G. M. Filho, B. A. Callander, N. Harris, A. Kattenberg and K. Maskell. 1996. Climate change 1995: the science of climate change. Cambridge, etc., Cambridge University Press.

Hulme, M. 1991. An intercomparison of model and observed global precipitation climatologies. Geophys. Res. Lett., 18(9), 1715-1718.

Johnsen, S. J. and 9 others. 1992. Irregular glacial interstadials recorded in a new Greenland ice core. Nature, 359 (6393), 311-313.

Maggi, V. 1996. Profili di densità e modelli profondità/densità su carote di nevato prelavate in alcuni ghiacciai della Terra Vittoria Settentrionale (Antartide). Geogr. Fis. Din. Quat., 18, 287-294.

Maggi, V. and 8 others. 1998. 70 years of northern Victoria Land (Antarctica) accumulation rate. Ann. Glaciol., 27 (see paper in this volume).

Mosley-Thompson, E. and L. G. Thompson. 1982. Nine centuries of microparticle deposition at the South Pole. Quat. Res., 17(1), 1-13.

Moulin, C., C. E. Lambert, F. Dulac and U. Dayan. 1997. Control of atmospheric export of dust from North Africa by the North Atlantic Oscillation. Nature, 387 (6634), $691-694$.

Mounier, L. 1988. Étude des microparticules insolubles deposées dans la glace Antarctique au cours du dernier cycle climatique. (Thèse du doctorat, Université de Joseph Fourier et CNRS, Grenoble.)

Petit, J.-R., L. Mounier, J. Jouzel, Ye. S. Korotkevich, V. M. Kotlyakov and C. Lorius. 1990. Palaeoclimatological and chronological implications of the Vostok core dust record. Nature, 343(6253), 56-58.

Pye, K. 1987. Aeolian dust and dust deposits. London, Academic Press.

Royer, A., M. de Angelis and J.-R. Petit. 1983. A 30,000 year record of physical and optical properties of microparticles from an East Antarctic ice core and implications for paleoclimate reconstruction models. Climatic Change, 5(4), 381-412.

Shaw, G. E. 1989. Aerosol transport from sources to ice sheets. In Oeschger, H. and C. C. Langway, Jr, eds. The environmental record in glaciers and ice sheets. Chichester, etc., John Wiley and Sons, 13-27.

Tegen, I., A. Lacis and I. Fung. 1996. The influences on climate forcing on mineral aerosols from disturbed soils. Nature, 380 (6573), 419-422.

Thompson, L. G. 1992. Ice core evidence from Peru and China. In Bradley, R. S. and P. D. Jones, eds. Climate since A.D. 1500. London and New York, Routledge, 517-548.

Udisti, R., S. Becagli, R. Traversi, S. Vermigli and G. Piccardi. 1998. Preliminary evidence of a biomass-burning event from a 60 year-old firn core from Antarctica by ion chromatographic determination of carboxylic acids. Ann. Glaciol., 27 (see paper in this volume). 